\title{
І. ГЕНТШЕЛЬ
}

\author{
Університет ім. Карла фон Оссецького (Інститут славістики) \\ м. Ольденбург, Німеччина \\ Електронна пошта: gerd.hentschel@uol.de \\ https://orcid.org/0000-0003-2034-1577
}

\section{О. О. ТАРАНЕНКО}

\author{
Інститут мовознавства ім. О. О. Потебні НАН України \\ м. Київ, Україна \\ Електронна пошта: oataran99@gmail.com \\ https://orcid.org/0000-0002-0269-8954
}

\section{ДВОМОВНІСТЬ ЧИ ТРИКОДОВІСТЬ: УКРАЇНСЬКА МОВА, РОСІЙСЬКА МОВА І «СУРЖИК» В УКРАЇНІ (аналіз і лінгвістично-географічне картографування) ${ }^{1}$}

\begin{abstract}
Пропоноване дослідження має на меті показати, що різну частотність використання в повсякденному житті України української мови, російської мови і «суржику» можна описати й картографувати як континуум мовної «трикодовості». У цьому плані стаття відрізняється від попередніх досліджень на теми мовної ситуації в сучасній Україні, автори яких звичайно відштовхуються від факту історико-політичного розмежування субрегіонів країни i, як правило, говорять про іiі чіткий, однозначний поділ на переважно українськомовний (з охопленням Заходу і Центру) і переважно російськомовний (з охопленням Сходу і Півдня) регіони. Підхід, запропонований у статті, використовує емпіричні дані щодо використання трьох мовних кодів (за самооцінками респондентів) як основу для структурування мовної ситуації в Україні. За допомогою кластерного аналізу розглядаються найвищі частотності використання мовних кодів в окремих областях, які потім групуються за більшими регіонами, що супроводжується поясненнями їхнього внутрішнього варіювання. Результатом дослідження $\epsilon$ не тільки більш континуальна (цілісна й послідовна), а й більш логічна й зрозуміла картина мовного ландшафту сучасної України.
\end{abstract}

1 Пропонована стаття є дещо переробленою версією попередньої статті англійською мовою: [Hentschel, Taranenko 2021], яка також містила певну інформацію, відому українському читачеві. Вона грунтується на результатах двох проєктів: a) «Варіативність і стабільність у змішаному субстандарті в умовах широких та стабільних у часі мовних контактів: українсько-російський “суржик” в Україні» під керівництвом Г. Гентшеля (м. Ольденбург, Німеччина), профінансованого Фондом імені Фріца Тіссена (Кельн, Німеччина); б) «Гібридизація 3 двох сторін: українсько-російське і російсько-українське змішування кодів у контексті соціолінгвістичної ситуації на півдні України вздовж узбережжя Чорного моря» під керівництвом Т. Ройтера (м. Клагенфурт, Австрія) і Г. Гентшеля (Ольденбург), який спонсорується в рамках австрійсько-німецького партнерства FWF - Der Wissenschaftsfonds (№ I 4189-G30) i Deutsche Forschungsgemeinschaft (DFG, № 419468937), у співпраці 3 Т. Кузнєцовою (м. Одеса, Україна). Автори висловлюють вдячність О. Палінській (Ольденбург) за різні коментарі до попередньої версії статті та К. Берд (Берлін) за переклад. Карти створені Т. Робберсом (Ольденбург).

(C) Г. ГЕНТШЕЛЬ, О. О. ТАРАНЕНКО, 2022 
Flier M. (2000). The rules of engagement. Harvard Ukrainian Studies 22. 113- 136.

Hentschel G. (2017). Eleven Questions and Answers about Belarusian-Russian Mixed Speech («Trasyanka»). Russian Linguistics, 41(1), 17-42.

Hentschel G. (2018). Die weißrussische «Trasjanka» und der ukrainische «Suržyk»: grundlegende quantitativ-qualitative soziolinguistische Ähnlichkeiten und Unterschiede. Deutsche Beiträge der deutschen Slavistik zum XVI. Internationalen Slavistenkongress, Belgrad, August 2018 (Reihe Die Welt der Slaven. Sammelbände — Sborniki). S. Kempgen, M. Wingender, L. Udolph (Eds.). München, 127-138.

Hentschel G., Kittel B. (2011). Weißrussische Dreisprachigkeit? Zur sprachlichen Situation in Weißrussland auf der Basis von Urteilen von Weißrussen über die Verbreitung «ihrer Sprachen» im Lande. Wiener Slawistischer Almanach. Band 67, 107-135.

Hentschel G., Taranenko O. (2015). Die Sprachenlandschaft der zentralen Ukraine: Ukrainisch, Russisch, 'Suržyk'. Verwendung — Kompetenz — nationale Positionierung. Die Welt der Slaven LX. 248-275.

Hentschel G., Zeller J. P. (2016). Meinungen und Einstellungen zu Sprachen und Kodes in zentralen Regionen der Ukraine. Zeitschrift für Slawistik, 61(4), 636-661.

Hentschel G., Zeller J. P. (2017). Aspekte der Sprachverwendung in zentralen Regionen der Ukraine. Wiener Slavistischer Almanach 79, (1), 37-60.

Hentschel G., Taranenko O. (2021). Bilingualism or tricodalism: Ukrainian, Russian and «Suržyk» in Ukraine: analysis and linguistic-geographical mapping. Die Welt der Slaven. Jg. 66. Heft 1. 268-299.

Identychnist hromadian Ukrainy v novykh umovakh: stan, tendencii, rehionalni osoblyvosti (2016). Nacionalna bezbeka i oborona, (3-4), 161-162. URL: http://razumkov. org.ua/uploads/journal/ukr/NSD161-162_2016_ukr.pdf, pp. 7-8, 70-72, 86 (last accessed: 12.08.2020). [In Ukrainian].

Konsolidatsiia ukrainskoho suspilstva: Vyklyky, mozhlyvosti, shliakhy (2016). = Nacional'na bezbeka i oborona, (7-8), 165-166. URL: http://razumkov.org.ua/uploads/ journal/ukr/NSD165-166_2016_ukr.pdf (last accessed: 12.08.2020). [In Ukrainian].

KIIS. (2020). Koho ukraintsi khotily b bachyty predstoiatlem ob'yednanoi tserkvy. URL: http://kiis.com.ua/?lang=ukr\&cat=reports\&id=958\&page=1 (last accessed: 12.08.2020). [In Ukrainian].

Kurohtina T. (2009). Surzhyk v internete. Vestnik Moskovskogo Universiteta, seriya 9, Filologiya, (2), 101-112. [In Russian].

Menzel Th., Hentschel G. (2017). Flexionsmorphologische Irregularität im innerslavischen Sprachkontakt. Sprachinhärente Präferenzen oder politisch-soziale Dominanz: Russisch vs. Weißrussisch / Ukrainisch — Polnisch vs. Kaschubisch / Lemkisch. Frankfurt a.M.

Moser M. (2016). «Surzhyk» chy «surzhyky»? Ukrainska mova, (1), 27-54.

Taranenko O. (2013). Variantnist vs. stabilnist u strukturi ukrainsko-rosiiskoho 'suržyku' (URS): sukupnist idiolektiv vs. sotsiolekt. Variation und Stabilität in Kontaktvarietäten: Beobachtungen zu gemischten Formen der Rede in Weißrussland, der Ukraine und Schlesien (Studia Slavica Oldenburgensia, 21). Gerd Hentschel (Ed.). Oldenburg, 27-62.

Taranenko O. (2014). Ukrainisch-russischer Suržyk: Status, Bewertungen, Tendenzen, Prognosen. Trasjanka und Suržyk - gemischte weißrussisch-russische und ukrainisch-russische Rede: Sprachlicher Inzest in Weißrussland und der Ukraine? Hentschel G., O. Taranenko, S. Zaprudski (Eds.). Frankfurt a.M., 265-288.

Trasjanka und Suržyk - gemischte weißrussisch-russische und ukrainisch-russische Rede. Sprachlicher Inzest in Weißrussland und der Ukraine? (2014). Hentschel G., Taranenko O., Zaprudski S. (Eds.). Frankfurt a.M.

Zeller J. P. (2018). Zum ukrainisch-russischen Sprachkontakt: Phonische Variation im ukrainischen «Suržyk» im Vergleich mit der weißrussischen «Trasjanka». Deutsche Bei- 
träge der deutschen Slavistik zum XVI. Internationalen Slavistenkongress (Belgrad, August 2018). S. Kempgen, M. Wingender, L. Udolph (Eds.). München, 365-374.

G. HENTSCHEL

University of Oldenburg (Slavic department)

Oldenburg, Germany

E-mail: gerd.hentschel@uol.de

https://orcid.org/0000-0003-2034-1577

O. O. TARANENKO

O. O. Potebnia Institute of Linguistics of the National Academy of Sciences of Ukraine

Kyiv, Ukraine

E-mail: oataran99@gmail.com

https://orcid.org/0000-0002-0269-8954

\section{BILINGUALISM OR TRICODALISM: UKRAINIAN, RUSSIAN AND «SURŽYK» IN UKRAINE (analysis and linguistic-geographical mapping)}

The study aims to show that the different usage frequencies of Ukrainian, Russian and «Suržyk» in everyday life in Ukraine can be described and mapped as a continuum of «tricodalism». This sets it apart from previous representations that usually assume a historical-political demarcation of sub-areas and consequently tend to indicate a linguistic bisection of the country into a Ukrainian-speaking area encompassing the west and the central region, and a Russian-speaking area in the east and south. The approach proposed here employs empirical data on usage of the three codes as the basis for its structuration. Starting from the mean frequencies of code usage in individual oblasts, a cluster analysis groups these into larger areas and clarifies their internal variation. This result is not just a more continuous picture of the linguistic landscape in Ukraine, but also a more coherent one.

Keywords: language situation in Ukraine, Ukrainian-Russian bilingualism, Ukrainian-Russian «suržyk», sociolinguistics, linguistic cartography, language contact.

Дата надходження до редакції - 29.11.2021

Дата затвердження редакцією - 12.12.2021 